\title{
CHEMICAL COMPOSITION AND ANTI-INFLAMMATORY ACTIVITY OF KITAIBELIA BALANSAE BOISS.
}

\author{
GÖKÇE ŞEKER KARATOPRAK ${ }^{1 *}$, LEYLA PAŞAYEVA ${ }^{1}$, ESRA KÖNGÜL ŞAFAK ${ }^{1}$, FATIH \\ GÖGER ${ }^{2}$, OSMAN TUGAY $^{3}$, MÜBERRA KOŞAR $^{4}$
}

${ }^{1}$ Department of Pharmacognosy, Faculty of Pharmacy, Erciyes University, Kayseri, Turkey

${ }^{2}$ Department of Pharmacognosy, Faculty of Pharmacy, Anadolu University, Eskişehir, Turkey

${ }^{3}$ Department of Botany, Faculty of Art and Science, Selçuk University, Konya, Turkey

${ }^{4}$ Department of Pharmacognosy, Faculty of Pharmacy, Eastern Mediterranean University, Famagusta, North Cyprus, via Mersin-10 Turkey

*corresponding author: gskaratoprak@gmail.com

\begin{abstract}
Aerial part extracts of Kitaibelia balansae Boiss. were examined for their phenolic contents, as well as anti-inflammatory activities. The chemical compositions of the extracts were analysed by spectrophotometric and chromatographic (HPLC/ MS/MS and HPLC-PDA) approaches. To measure anti-inflammatory activity, the effects of the extracts on nitric oxide (NO) and Tumour Necrosis Factor- $\alpha$ (TNF- $\alpha$ ) levels were measured in lipopolysaccharide (LPS) treated murine macrophage cell line (RAW 264.7). The ethyl acetate fraction was found to be abundant in phenolic compounds $\left(259.78 \pm 15.07 \mathrm{mg}_{\mathrm{GAE}} /\right.$ $\mathrm{g}_{\text {extract}}$ ). Rutin was identified as the major compound in all the extracts. The ethyl acetate fraction potentially inhibited NO and TNF- $\alpha$ production $(37.26 \mu \mathrm{M}$ and $1781.524 \mathrm{pg} / \mathrm{mL}$, respectively, $6 \mathrm{~h})$ in LPS induced cells.
\end{abstract}

\section{Rezumat}

Extractele obținute din părți aeriene de Kitaibelia balansae Boiss. au fost teste privind conținutul fenolic şi efectul antiinflamator. Compoziția chimică a extractelor a fost determinată folosind metode spectrofotometrice şi cromatografice (HPLC/MS/MS și HPLC-PDA). Au fost determinate valorile NO și TNF- $\alpha$ folosind o linie de celule murine de macrofage (RAW 264.7) tratate cu lipopolizaharide (LPS). Fracția de acetat de etil s-a dovedit a fi abundentă în compuși fenolici $\left(259,78 \pm 15,07 \mathrm{mg}_{\mathrm{GAE}} / \mathrm{g}_{\text {extract }}\right)$. Rutinul a fost identificat drept compus principal în toate extractele. Fracția de acetat de etil a inhibat producția de NO și TNF- $\alpha(37,26 \mu \mathrm{M}$ și, respectiv, $1781.524 \mathrm{pg} / \mathrm{mL}, 6$ h) în celulele tratate cu LPS.

Keywords: Kitaibelia balansae, Malvaceae, HPLC/MS/MS, anti-inflammatory

\section{Introduction}

Medicinal and aromatic plants contain bioactive compounds with specific (bio) chemical or organoleptic properties that enable the use of in the pharmaceutical field [1]. Phytochemicals that are naturally occurring in the plants have various therapeutic properties, and also, they are effective in the treatment of chronic and even infectious diseases. Now there is a need for the new, safe, potent, non-toxic anti-inflammatory plantbased drugs because of the long-term use of nonsteroidal anti-inflammatory drugs (NSAIDS) adverse side effects [16].

Kitaibelia balansae Boiss. is a member of Malvaceae and is a tall herb with spreading-pilose stems. It is endemic to Turkey and it differs from the European $K$. vitifolia Willd. in its lanceolate (not ovate) stipules and triangular (not trifid) leaves [6]. To our knowledge there are no studies related to chemical composition and biological properties of this plant. The other member of the genus Kitaibelia vitifolia Willd. is endemic to Serbia is well known for its anti-oxidant and antimicrobial activity. Many studies have illuminated the chemical composition of $K$. vitifolia and the results have shown that rosmarinic acid, apigenin, chrysoeriol, kaempferol, quercetin 3-O- $\beta$ glucopyranoside and 3-O-rutinoside were present in this specie. Rosmarinic acid has been reported as the major phenolic compound and it was expressed that this compound is responsible for the antioxidant effects of $K$. vitifolia [13, 14].

To date, the biological activity and chemical composition of $K$. balansae has not been investigated, and in view of the lack of information on this specie, it is important to investigate the secondary metabolites found in endemic $K$. balansae and to question the possible anti-inflammatory activity of the plant. For all these reasons we aimed to: 1 ) investigate the chemical composition of $K$. balansae aerial part $70 \%$ methanol extract and its $n$-butanol and ethyl acetate fractions with spectrophotometric and chromatographic techniques (HPLC and LC/MS/MS); 2) examine the potential anti-inflammatory effects of $K$. balansae extracts on LPS induced macrophage cell lines. 


\section{Materials and Methods}

Plant Material, Chemicals and Cell Line

Aerial parts of $K$. balansae were collected in June 2015, in Central Anatolia Region of the province of Hadım-Konya, and plant specimen was identified by Prof. Dr. Osman Tugay from Selçuk University and stored at Selçuk University, Art and Science Faculty Herbarium, Turkey (KNYA 26906). All standards were purchased from Sigma Chemical Company (St. Louis, MO, USA). Indomethacin was purchased from Deva Holding AŞ (İstanbul, Turkey). Cell line (RAW 264.7) has been obtained from the collection of American Type Culture Collection (ATCC Manassas, VA, USA).

Extract Preparation

Air dried $K$. balansae herb (135 g) was grounded and extracted with $750 \mathrm{~mL}$ of $70 \%$ methanol in a water bath $\left(40^{\circ} \mathrm{C}\right)$ with mechanical shaking, followed by filtration. The same procedure was repeated two times using the same plant residue and the obtained filtrates were combined. The solvent of combined extract was removed in vacuo $\left(40^{\circ} \mathrm{C}\right) .20 \mathrm{~g}$ of $70 \%$ methanol extract $(\mathrm{kbMeOH})$ was obtained, which was then fractionated with ethyl acetate and $n$-butanol. Both ethyl acetate (kbEtOAc) and $n$-butanol $(\mathrm{kbBuOH})$ fractions were concentrated in vacuo. All extracts were stored at $-20^{\circ} \mathrm{C}$ after lyophilisation.

Total Phenolic and Flavonoid Contents

The Folin-Ciocâlteu method using gallic acid was used to determine total phenolic content [21]. Aluminium chloride colorimetric assay using catechin was used to determine total flavonoids content [25].

Chemical composition analysis with LC-MS/MS and HPLC systems

LC-MS/MS analysis were carried out with Shimadzu 20A HPLC system coupled to an Applied Biosystems 3200 Q-Trap LC-MS/MS instrument equipped with an ESI source operating in negative ion mode. Octadecyl silica gel analytical column (GL Science Intersil ODS $250 \times 4.6 \mathrm{~mm}$, i.d., $5 \mu \mathrm{m}$ particle size) was used for the chromatographic separation with $0.3 \mathrm{~mL} / \mathrm{min}$ flow rate. The method we used was presented in a previous article [17].

HPLC experiments were performed with Agilent HP1100. Reverse-phase Mediterrenean-C18 analytical column $(250 \times 4.6 \mathrm{~mm}$ i.d., $5 \mu \mathrm{m}$ particle size $)$ was used to perform separations operating at $22^{\circ} \mathrm{C}$ with $1 \mathrm{~mL} / \mathrm{min}$ flow rate. Extracts were prepared at $1 \mathrm{mg} / \mathrm{mL}$ concentration prior to injection. Components were identified by comparison of their retention times to those of authentic standards under identical analysis conditions and UV spectra using our in-house PDA library. The method we used was presented in a previous article [17].
Cell culture and cell viability-MTT assay

The murine macrophage RAW 264.7 cell line was cultured in Dulbecco's Modified Eagle's medium (DMEM) supplemented with foetal bovine serum (FBS), streptomycin, and penicillin $10 \%, 100 \mu \mathrm{g} / \mathrm{L}$, $100 \mathrm{IU} / \mathrm{mL}$, respectively, at $37^{\circ} \mathrm{C}$ with $5 \% \mathrm{CO}_{2}$.

The procedure consisted in the technique described by Ilieva et al. The cells were treated with extracts ranging in concentration between $25-400 \mu \mathrm{g} / \mathrm{mL}$. Absorbance was measured at $570 \mathrm{~nm}$ with a multiwell ELISA reader [10].

Measurement of NO and TNF- $\alpha$ level

The RAW 264.7 cells were seeded $5 \times 10^{5}$ cells/well in 12 well plates and cultured for $24 \mathrm{~h}$. $100 \mu \mathrm{g} / \mathrm{mL}$ concentrated $\mathrm{kbMeOH}$, kbEtOAc and $\mathrm{kbBuOH}$ extracts of $K$. balansae were prepared in DMEM without FBS, to give a total volume of $500 \mu \mathrm{L}$ per well of plate. Then media of each well were removed, media containing extracts were replaced. After $3 \mathrm{~h}$ and $6 \mathrm{~h}$ treatment with extracts, cells were induced with $1 \mu \mathrm{g} / \mathrm{mL}$ of LPS for $24 \mathrm{~h}$. Indomethacin was used as a reference drug at $25 \mu \mathrm{M}$ concentration in the experiments. Culture supernatants were collected after treatment of LPS.

Culture supernatants and Griess reagent $[0.1 \% \mathrm{~N}$ (1-naphthyl)-ethylene diamine, 1\% sulphanilamide in $5 \%$ phosphoric acid] were mixed with the equal volume $(50 \mu \mathrm{L})$. The absorbance was taken at $550 \mathrm{~nm}$ with ELISA after $10 \mathrm{~min}$ incubation. Sodium nitrite was used as a standard between $2.5-100 \mu \mathrm{M}$ concentrations [18].

TNF- $\alpha$ cytokine level was quantified using enzymelinked immunosorbent assay (ELISA) kit, according to the manufacturer's instructions (eBioscience Inc., San Diego, CA).

Statistical analysis

Data are given as mean values $\pm 95 \%$ confidence interval. SPSS software, version 12.0 was used for all statistical analyses. ANOVA procedures were used to assess variance analysis. Significance of differences between means were determined by comparison test of Tukey's pairwise, $\mathrm{p}<0.05$ level.

\section{Results and Discussion}

\section{Total Phenolic and Flavonoid Contents}

The plant raw extracts often contain significant amounts of carbohydrates and/or lipid material and the crude extracts may therefore have a low concentration of phenolics [5]. The crude extract was partitioned into fractions with ethyl acetate and $n$-butanol to concentrate and obtain polyphenol-rich fractions. Based on the values of total phenol and flavonoid content, the fractions have higher total phenol and flavonoid content than crude $70 \%$ methanol extract (Table I). 
Yields of extracts, total phenols and flavonoids data for $K$. balansae extracts

\begin{tabular}{|c|c|c|c|}
\hline Extracts* and standards & Yield & $\begin{array}{l}\text { Total Phenols }{ }^{a} \\
{\left[\mathrm{mg}_{\mathrm{GAE}} / \mathrm{g}_{\text {extract }}\right]}\end{array}$ & $\begin{array}{c}\text { Total Flavonoids }^{b} \\
{\left[\mathrm{mg}_{\mathrm{CA}} / \mathrm{g}_{\text {extract }}\right]} \\
\end{array}$ \\
\hline kbMeOH & $17 \%(24.16 \mathrm{~g})$ & $110.350 \pm 4.92$ & $39.443 \pm 0.55$ \\
\hline kbEtOAc & $14.6 \%(2.92 \mathrm{~g})$ & $259.780 \pm 15.07$ & $90.693 \pm 1.56$ \\
\hline kbBuOH & $31.7 \%(6.34 \mathrm{~g})$ & $146.447 \pm 0.18$ & $51.287 \pm 4.57$ \\
\hline
\end{tabular}

$\mathrm{kbMeOH}=70 \%$ methanol extract; $\mathrm{kbEtOAc}=$ ethyl acetate fraction; $\mathrm{kbBuOH}=n$-butanol fraction.

${ }^{a}=$ Total phenols expressed as mg gallic acid/gram (dry weight) of extract. ${ }^{b}=$ Total flavonoids expressed as mg catechin/gram (dry weight) of extract. Values are given as means \pm standard error $(n=3)$.

\section{Chemical composition analysis with LC-MS/MS and} HPLC systems

The qualitative-quantitative analyses of the extracts carried out using LC/MS/MS and HPLC systems and the results presented in Table II and Table III, respectively. In the present work, organic acids, phenolic acids and flavonoids were detected in a negative ionization mode. At the beginning of the analysis, $[\mathrm{M}-\mathrm{H}]^{-}$ion at $\mathrm{m} / \mathrm{z}, 179$ as well as a fragment ion at $\mathrm{m} / \mathrm{z}, 135$, revealing the compound to be caffeic acid [3]. A very polar organic acid such as malic acid was detected in accordance with the literature [7]. A hydroxycinnamic acid derivative (compound 3) was identified as coumaric acid for its specific $\mathrm{MS}^{2}$ product ions (m/z 163 and 119) [8]. Molecular ion [M-H] $(\mathrm{m} / \mathrm{z}$ 385) was defined as feruloylglucaric acid by the MS/MS fragment ions $m / z 209$ and $m / z \quad 193$ [23]. Rutin was suggested for the precursor ion at $m / z 609$. The MS and MS/MS spectra showed product ions $[\mathrm{M}-\mathrm{H}]^{-}$at $m / z, 301$ and $m / z 271$ [22]. Compound with a retention time of $20 \mathrm{~min}$, having $\mathrm{m} / z 593$ $[\mathrm{M}-\mathrm{H}]^{-}$molecular ion was cleaved into $\mathrm{m} / \mathrm{z} 285$ and 255 product ions in MS/MS analysis and as a result, it was determined that this compound was kaempferol coumaroyl hexoside [20]. Similarly, compound with a retention time of $21.2 \mathrm{~min}$, which has a molecular ion $m / z$ of $447[\mathrm{M}-\mathrm{H}]^{-}$and $m / z 285$ (kaempferol $[\mathrm{M}-\mathrm{H}]^{-}$Glc) and $m / z$ 273, 257,151 fragment ions, defined as kaempferol -3-O-glucoside [22].

After the loss of a glucose unit (-162 Amu) from $[\mathrm{M}-\mathrm{H}]^{-}$ion at $m / z, 463$, fragment ion [quercetin-H] $]^{-}$at $\mathrm{m} / \mathrm{z} 301$ obtained and this was identified as quercetin glucoside [22]. At 20.3, a peak with $\mathrm{m} / \mathrm{z} 623$ fragmented to $m / z, 315$ and 300 which was in agreement with the fragmentation pattern of methyl-quercetinrhamnoside-hexoside [2]. Other detected quercetin glycoside was determined to be quercetin acetyl hexoside $[\mathrm{M}-\mathrm{H}]^{-}$at $\mathrm{m} / \mathrm{z}$ 505) relative to the product ions corresponding to the losses of hexosyl moieties (-162 Amu) and the acetyl residue (-42 Amu) [9]. Kaempferol-3-O-glucoside was subsequently sequenced with the losses of aglycone fragment ions $m / z 285$ (284), $m / z$ 255, m/z 227 from [M-H] ${ }^{-}$with glucose [4]. The ion at $[\mathrm{M}-\mathrm{H}]-m / z, 489$ was identified as kaempferol-3-O-acetylglucoside in the parent fragment $m / z 285$ (after loss 204 Amu: acetyl-hexose). m/z 519, $\mathrm{MS}^{2}$ product ions at 315 and 300 , corresponding to the initial loss of 204 Amu: acetylhexoside [11] and then 15 Amu: a methyl group, was assigned as methyl quercetin acetylhexoside [15]. At 28.6, a peak with $m / z, 301$ fragmented to $m / z, 228,179$ and 151 which was consistent with the fragmentation pattern of quercetin [15]. Regarding the HPLC analysis of $K$. vitifolia, rosmarinic acid was found to be the main component, and lower content was observed for caffeic acid and $p$-hydroxy benzoic acid [13]. In both species, $K$. balansae and $K$. vitifolia, caffeic acid, ferulic acid, $p$-coumaric acid and quercetin were found similar, but major phenolic compounds are different from each other.

Table II

LC/MS/MS results of $K$. balansae extracts

\begin{tabular}{|c|c|c|c|c|}
\hline \multicolumn{2}{|c|}{$t_{\mathrm{R}}(\min )[\mathrm{M}-\mathrm{H}]^{-}(\mathrm{m} / z)$} & \multirow{2}{*}{$\frac{\text { Ms/Ms }(\boldsymbol{m} / z)}{135}$} & \multirow{2}{*}{$\begin{array}{c}\text { Identification } \\
\text { Caffeic acid }\end{array}$} & \multirow{2}{*}{$\begin{array}{c}\text { Extracts } \\
\mathrm{kbBuOH} ; \mathrm{kbEtOAc} ; \mathrm{kbMeOH}\end{array}$} \\
\hline 8.5 & 179 & & & \\
\hline 9.9 & 133 & 115 & Malic acid & $\mathrm{kbMeOH}$ \\
\hline 15.69 & 163 & 119 & $p$-Coumaric acid & $\mathrm{kbMeOH}$ \\
\hline 17.2 & 385 & 209,191 & Feruloylglucaric acid & $\mathrm{kbBuOH}$ \\
\hline 18.5 & 609 & 301,271 & Rutin & kbBuOH; kbEtOAc; kbMeOH \\
\hline 19.7 & 593 & $285,255,227$ & Kaempferol coumaroyl hexoside & $\mathrm{kbBuOH}$; kbEtOAc; kbMeOH \\
\hline 20.0 & 463 & 300,271 & Quercetin glucoside & kbBuOH; kbEtOAc; kbMeOH \\
\hline 20.3 & 623 & 315,300 & Methyl-quercetin-rhamnoside-hexoside & kbBuOH; kbEtOAc; kbMeOH \\
\hline 20.68 & 505 & $463,300,271$ & Quercetin acetylhexoxide & kbBuOH; kbEtOAc; kbMeOH \\
\hline 21.2 & 447 & $284,255,227$ & Kaempferol-3-O-glucoside & $\mathrm{kbMeOH} ; \mathrm{kbEtOAc}$ \\
\hline 22.34 & 489 & $327,285,227$ & Kaempferol-3-O-acetylglucoside & kbBuOH; kbEtOAc; kbMeOH \\
\hline 23.1 & 519 & $\begin{array}{l}315,300 \\
285,271\end{array}$ & Methyl quercetin acetylhexoside & $\begin{array}{c}\text { kbBuOH; kbEtOAc, } \\
\text { kbMeOH }\end{array}$ \\
\hline 28.6 & 301 & $228,179,151$ & Quercetin & kbEtoAC \\
\hline
\end{tabular}

$\mathrm{kbMeOH}=70 \%$ methanol extract; $\mathrm{kbEtOAc}=$ ethyl acetate fraction; $\mathrm{kbBuOH}=n$-butanol fraction 


\section{Compounds}

Caffeic acid

p-Coumaric acid

$\underline{\text { Rutin }}$

Quercetin

kbMeOH
t.a
t.a
$25.909 \pm 0.408$
n.d

kbEtOAc

$0.294 \pm 0.017$

$0.602 \pm 0.014$

$177.032 \pm 3.500$

t.a

Table III

HPLC results of $K$. balansae extracts

$* \mathrm{kbMeOH}=70 \%$ methanol extract; $\mathrm{kbEtOAc}=$ ethyl acetate fraction; $\mathrm{kbBuOH}=n$-butanol fraction

$\&=\mathrm{mg} / \mathrm{g}$, mean $\pm \mathrm{SD}$, n.d. $=$ not detected; t.a. $=$ trace amount.

\section{Cell Viability}

In order to measure $\mathrm{NO}$ and $\mathrm{TNF}-\alpha$ levels before cell viability assay, the MTT test was performed. The results obtained by the MTT cell viability assay are given in Figure 1. In this study, a $50 \mu \mathrm{g} / \mathrm{mL}$ concentration which gives better cell viability percentages has been used for further in vitro anti-inflammatory investigations.

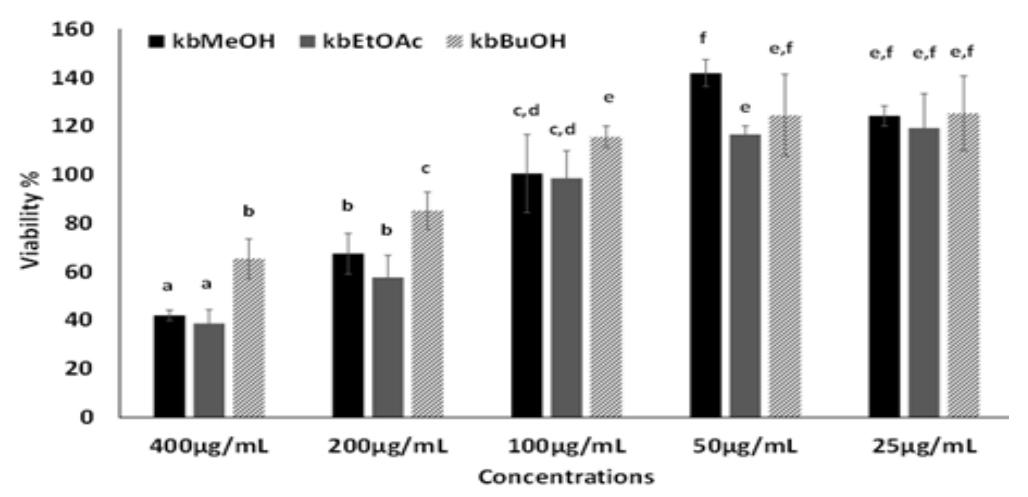

Figure 1.

Cytotoxic effects of $K$. balansae extracts on RAW 264.7 cells.

$\mathrm{kbMeOH}=70 \%$ methanol extract; $\mathrm{kbEtOAc}=$ ethyl acetate fraction; $\mathrm{kbBuOH}=n$-butanol fraction. Each value is the mean \pm standard error of triplicate analysis. Values within a column followed by the same letter and number (a-f) are not significantly $(\mathrm{p}>0.05)$ different.

\section{Measurement of $N O$ and $T N F-\alpha$ level}

LPS induction of iNOS and production of NO are important inflammatory responses of macrophage cells. NO excessive induction leads to various deleterious responses such as tissue damage, septic shock, apoptosis and necrosis [12].

The results of nitric oxide measurement revealed that $K$. balansae extracts pre-treatment provides a timedependent effect on LPS-stimulated NO production in RAW 264.7 cells. LPS application significantly increased nitrite release in control group $(70.36 \pm 3.12$ $\mu \mathrm{M})(\mathrm{p}<0.05)$ compared to control conditions without
LPS $(9.58 \pm 0.36 \mu \mathrm{M})$. The results are given in Table IV. However, LPS-induced nitrite release reduced significantly by the pre-treatment with $50 \mu \mathrm{g} / \mathrm{mL} K$. balansae extracts, $(\mathrm{p}<0.05)$, especially with ethyl acetate extract $(49.16 \pm 2.66 \mu \mathrm{M} 3 \mathrm{~h}, 37.76 \pm 1.20 \mu \mathrm{M}$ $6 \mathrm{~h}$ ), at $3 \mathrm{~h}$ and $6 \mathrm{~h}$, compared to LPS alone. The results of this study highlighted that the duration of treatment of extracts affected nitrite release from macrophages. In $6 \mathrm{~h}$ treatment, $70 \%$ methanol extract and ethyl acetate fraction showed significant anti-inflammatory effects compared to $3 \mathrm{~h}$ pre-treatment ( $\mathrm{p}<0.05$ ).

Inhibitory effects of $K$. balansae extracts on NO levels and TNF- $\alpha$ production in RAW 264.7 cells

\begin{tabular}{l|ccc}
\hline \multicolumn{1}{c|}{ Extracts } & \multicolumn{2}{|c|}{ Nitrite concentration $(\boldsymbol{\mu M})$} & TNF- $\boldsymbol{\alpha}(\mathbf{p g} / \mathbf{m L})$ \\
& $\mathbf{3 ~ h}$ & $\mathbf{6 ~ h}$ & $\mathbf{6 ~ h}$ \\
\hline $\mathrm{kbMeOH}$ & $52.1 \pm 0.35^{\mathrm{a}}$ & $45.23 \pm 2.77^{\mathrm{b}}$ & $2053 \pm 90.36^{\mathrm{a}, \mathrm{b}}$ \\
\hline $\mathrm{kbEtOAc}$ & $49.16 \pm 2.66^{\mathrm{a}, \mathrm{b}}$ & $37.76 \pm 1.20^{\mathrm{c}}$ & $1781.52 \pm 37.75^{\mathrm{a}}$ \\
\hline $\mathrm{kbBuOH}$ & $63.56 \pm 0.80^{\mathrm{d}}$ & $54.7 \pm 1.31^{\mathrm{a}, \mathrm{d}}$ & $2263.85 \pm 84.95^{\mathrm{b}}$ \\
\hline Indomethacin & $15.14 \pm 1.45^{\mathrm{e}}$ & $17.7 \pm 1.58^{\mathrm{e}}$ & $205 \pm 7.01^{\mathrm{c}}$ \\
\hline Control & $8.43 \pm 0.25^{\mathrm{f}}$ & $9.58 \pm 0.36^{\mathrm{f}}$ & $863.41 \pm 28.53^{\mathrm{d}}$ \\
\hline LPS group & $65.41 \pm 2.45^{\mathrm{g}}$ & $70.36 \pm 3.12^{\mathrm{g}}$ & $2654.82 \pm 138.18^{\mathrm{e}}$ \\
\hline
\end{tabular}

$\mathrm{kbMeOH}=70 \%$ methanol extract; $\mathrm{kbEtOAc}=$ ethyl acetate fraction; $\mathrm{kbBuOH}=n$-butanol fraction .

Each value is the mean \pm standard error of triplicate analysis. Values within a column followed by the same letter and number (a-g) are not significantly $(p>0.05)$ different. 
TNF- $\alpha$ is an important inflammatory mediator that activates leucocytes, enhances neutrophils and endothelial adhesion of monocytes, and promotes the synthesis of eicosanoids, which increases the migration of inflammatory cells in the intracellular matrix [10]. Pre-treatment of $K$. balansae extracts, decreased the LPS-induced releasing of the inflammatory cytokine TNF- $\alpha$ levels in RAW 264.7 cells (Table IV). LPS application increased TNF- $\alpha$ release in control group $(2654.82 \pm 138.18 \mathrm{pg} / \mathrm{mL})$ compared to control groups without LPS $(863.41 \pm 28.53 \mathrm{pg} / \mathrm{mL})(\mathrm{p}<0.05)$. This increasing was significantly reduced by pretreatment with ethyl acetate extract (1781.52 \pm 37.75$)$ at a concentration of $50 \mu \mathrm{g} / \mathrm{mL}$ at $6 \mathrm{~h}$, compared to LPS alone. No extract was found to be as active as indomethacin, an indole derivative nonsteroidal antiinflammatory drug (positive control).

LPS application to RAW 264.7 cells increases the release of inflammatory mediator $\mathrm{NO}$ and proinflammatory cytokine TNF- $\alpha$, compared to LPS (-) control group. However, pre-treated cells with ethyl acetate extract released significantly less NO and TNF- $\alpha$. The anti-inflammatory effect of ethyl acetate extract is related with the major phenolic compound, rutin, while several studies have found that rutin has an anti-inflammatory effect $[19,24]$.

\section{Conclusions}

The anti-inflammatory effect of the extracts investigated is closely related to their chemical composition. Compounds directly responsible for such biologically active compounds are polyphenols. However, in vivo studies needed to elucidate the mechanisms involved in the anti-inflammatory properties of $K$. balansae, and our future research will focus on in vivo studies.

\section{Acknowledgement}

Erciyes University Scientific Research Projects (THD2016-6600) supported this research.

\section{Conflicts of interest}

The authors declare no conflict of interests.

\section{References}

1. Alimpića A, Kneževića A, Milutinović M, Stević T, Šavikin K, Stajić M, Marković SD, Marin P, Matevski V, Duletić-Laušević S, Biological activities and chemical composition of Salvia amplexicaulis Lam. Extracts. Ind Crops Prod., 2017; 105: 1-9.

2. Apel L, Kammerer DR, Stintzing FC, Spring O, Comparative metabolite profiling of triterpenoid saponins and flavonoids in flower color mutations of Primula veris L. Int J Mol Sci., 2017; 18(1): pii: E153: 1-13.

3. Chen HJ, Inbaraj BS, Chen BH, Determination of phenolic acids and flavonoids in Taraxacum formosanum Kitam by liquid chromatography-tandem mass spectrometry coupled with a post-column derivatization technique. Int J Mol Sci., 2012; 13(1): 260-285.

4. Chen Y, Yu H, Wu H, Pan Y, Wang K, Jin Y, Zhang C, Characterization and quantification by LC-MS/MS of the chemical components of the heating products of the flavonoids extract in Pollen typhae for transformation rule exploration. Molecules, 2015; 20(10): 1835218366.

5. Dai J, Mumper RJ, Plant phenolics: extraction, analysis and their antioxidant and anticancer properties. Molecules, 2010; 15(10): 7313-7352.

6. Davis PH, Flora of Turkey and the East Aegean islands, Vol. 2. Edinburgh University Press; Edinburgh (United Kingdom), 1967.

7. Elsadig Karar MG, Kuhnert N, UPLC-ESI-Q-TOFMS/MS Characterization of phenolics from Crataegus monogyna and Crataegus laevigata (Hawthorn) leaves, fruits and their herbal derived drops (Crataegutt Tropfen). J Chem Biol Ther., 2015; 1(1): 1-23.

8. Fischer UA, Carle R, Kammerer DR, Identification and quantification of phenolic compounds from pomegranate (Punica granatum L.) peel, mesocarp, aril and differently produced juices by HPLC-DAD-

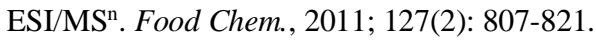

9. Guimarães R, Barros L, Dueñas M, Carvalho AM, Queiroz MJR, Santos-Buelga C, Characterisation of phenolic compounds in wild fruits from North Eastern Portugal. Food Chem., 2013; 141(4): 3721-3730.

10. Ilieva I, Ohgami K, Shiratori K, Koyama Y, Yoshida K, Kase S, Kitamei H, Takemoto Y, Yazawa K, Ohno S, The effects of Ginkgo biloba extract on lipopolysaccharide-induced inflammation in vitro and in vivo. Expl Eye Res., 2004; 79(2): 181-187.

11. Kajdžanoska, M, Gjamovski V, Stefova M, HPLCDAD-ESI-MS ${ }^{n}$ identification of phenolic compounds in cultivated strawberries from Macedonia. Maced J Chem Chem En., 2010; 29(2): 181-194.

12. Andreicuţ AD, Pârvu AE, Moț AC, Pârvu M, Fodor EF, Feldrihan V, Cătoi AF, Cecan M, Irimie A, Antiinflammatory and antioxidant effects of Mahonia aquifolium leaves and bark extracts. Farmacia, 2018; 66(1): 49-58.

13. Mašković $\mathrm{P}$, Solujić $\mathrm{S}$, Mihailović $\mathrm{V}$, Mladenović $\mathrm{M}$, Cvijović M, Mladenović J, Ac'amovic'-Đokovic G, Kurc'ubic' V, Phenolic compounds and biological activity of Kitaibelia vitifolia. J Med Food, 2011; 14(12): 1617-1623.

14. Matlawska I, Flavonoid compounds in the flowers of Kitaibelia vitifolia Willd. (Malvaceae). Acta Pol Pharm., 2000; 58(2): 127-131.

15. Mullen W, Yokota T, Lean ME, Crozier A, Analysis of ellagitannins and conjugates of ellagic acid and quercetin in raspberry fruits by $\mathrm{LC}-\mathrm{MS}^{\mathrm{n}}$. Phytochem., 2003; 64(2): 617-624.

16. Murugesan D, Deviponnuswamy R, Potential antiinflammatory medicinal plants. Int J Pharm Pharm Sci., 2014; 6(4): 43-49.

17. Şeker Karatoprak G, Göger F, Yerer MB, Koşar M, Chemical composition and biological investigation of Pelargonium endlicherianum root extracts. Pharm Biol., 2017; 55(1): 1608-1618.

18. Şeker Karatoprak G, İlgün S, Koşar M, Phenolic composition, anti-inflammatory, antioxidant, and 
antimicrobial activities of Alchemilla mollis (Buser) Rothm. Chem Biodivers., 2017; 14(9): 1-12.

19. Selloum L, Bouriche H, Tigrine C, Boudoukha C, Anti-inflammatory effect of rutin on rat paw oedema, and on neutrophils chemotaxis and degranulation. Exp Toxicol Pathol., 2003; 54(4): 313-318.

20. Simirgiotis MJ, Schmeda-Hirschmann G, Determination of phenolic composition and antioxidant activity in fruits, rhizomes and leaves of the white strawberry (Fragaria chiloensis spp. chiloensis form chiloensis) using HPLC-DAD-ESI-MS and free radical quenching techniques. J Food Compos Anal., 2010; 23(3): 545-553.

21. Singleton VL, Orthofer R, Lamuela-Raventós RM, Analysis of total phenols and other oxidation substrates and antioxidants by means of Folin-Ciocâlteu reagent. Method Enzymol., 1999; 299(14): 152-178.

22. Song C, Huang L, Rong L, Zhou Z, Peng X, Yu S, Fang N, Anti-hyperglycemic effect of Potentilla discolor decoction on obese-diabetic (Ob-db) mice and its chemical composition. Fitoterapia, 2012; 83(8): 1474-1483.

23. Spínola V, Pinto J, Castilho PC, Identification and quantification of phenolic compounds of selected fruits from Madeira Island by HPLC-DAD-ESI-MS ${ }^{\mathrm{n}}$ and screening for their antioxidant activity. Food Chem., 2015; 173: 14-30.

24. Yoo H, Ku SK, Baek YD, Bae JS, Anti-inflammatory effects of rutin on HMGB1-induced inflammatory responses in vitro and in vivo. Inflamm Res., 2014; 63(3): 197-206.

25. Zhishen J., Mengcheng $\mathrm{T}$, Jianming $\mathrm{W}$, The determination of flavonoid contents in mulberry and their scavenging effects on superoxide radicals. Food Chem., 1999; 64: 555-559. 